Cahiers $d u$ MONDE RUSSE

\section{Cahiers du monde russe}

Russie - Empire russe - Union soviétique et États indépendants

$57 / 4 \mid 2016$

Varia

\title{
Willard Sunderland, The Baron's Cloak, A History of the Russian Empire in War and Revolution
}

\author{
Nikolaus Katzer
}

\section{OpenEdition}

\section{Journals}

Electronic version

URL: http://journals.openedition.org/monderusse/10014

DOI: 10.4000/monderusse. 10014

ISSN: $1777-5388$

\section{Publisher}

Éditions de l'EHESS

\section{Printed version}

Date of publication: 1 October 2016

Number of pages: $927-924$

ISBN: 978-2-7132-2542-0

ISSN: $1252-6576$

\section{Electronic reference}

Nikolaus Katzer, « Willard Sunderland, The Baron's Cloak, A History of the Russian Empire in War and Revolution », Cahiers du monde russe [Online], 57/4 | 2016, Online since 01 October 2016, Connection on 23 September 2020. URL : http://journals.openedition.org/monderusse/10014 ; DOI : https:// doi.org/10.4000/monderusse.10014 


\section{Willard SUNDERLAND}

\section{The Baron's Cloak}

\section{A History of the Russian Empire in War and Revolution}

Ithaca: Cornell University Press, 2014, 368 p.

What a career-posthumously! We encounter here an ostracized eccentric after the passage of a century as an "imperial subject," predestined to provide a detailed account of the history of an entire empire. Baron Nikolai Roman Max von Ungern-Sternberg (1886-1921), the protagonist in Willard Sunderland's new study, was a notorious warlord in the Russian Civil War, allegedly accused of almost all the postwar atrocities Eurasia which came to the attention of the international public at the time. When the Bolsheviks captured him in August 1921, they immediately put him on trial in Novonikolaevsk. Ungern was executed and declared a non-person. His regime had profited from the chaos of the Civil War and for a time controlled a large area, although without fixed borders. It extended from southern Siberia across Mongolia and Tibet on to China, and only later could it be conquered. Unjustifiably, this final stage in the re-conquest of the peripheries by the Red Army stood in the shadow of the fronts in the West, long since pacified in the European area of the Empire. In this connection, one possible important factor was that Ungern was considered an even greater adventurer than other warlords. Referring to his un-predictability, he was denied even being capable of having a political agenda.

Sunderland, a profound expert of the Eurasian entanglements, casts light into the forest of prejudices and prejudgment, according the supposedly ephemeral (hi) story a new meaning. He is not the first author to rediscover Ungern for research, but is doubtless one of the most original. Thus, for example, Russian readers owe the breaching of the traditional Soviet taboo to the work of Leonid Iuzefovich. And are indebted to Sergei Kuz'min for a highly detailed biography as well as editions that balance the state of knowledge in a relatively sober manner, but en passant also serve to demystify various attempts by international, rightwing authors since the 1920s to play down the Baron or imbue his figure with hagiographic exaggerations. ${ }^{1}$ In addition, important spadework has been done by James Palmer in his superb, historically well-grounded travelogue journeying to the places where Ungern was active. On the trail of his hero, he paces off the horizon line, as it were, of an ideal-typical Greater Mongolia, such as may have been envisioned by the thwarted Genghis Khan redux. ${ }^{2}$

Sunderland is familiar with all branches of the field of Ungerniana, both the narrow core of serious literature as well as the far more frequent products of a modern demonology, which, seizing upon set pieces of more or less authenticated episodes, construct a caricature of the "last God of War," "White Knight" or "brutal Buddha." He magisterially leaves this panopticon of abominations behind, refuting it with a sovereign knowledge of the published and archival sources, and combs the historical sites for remainders of the distant swirl of events. What visual inspection no longer reveals to the discerning eye is ensured by his perusal of contemporary 
writings in different languages and of various disciplines, such as ethnology or the history of religions.

But ultimately Sunderland's study is impressive by dint of a concept that permits the historian to bind together and compress this abundance of material. On well over 300 pages, two-thirds of which comprise the body of text, and one-third his notes, bibliography and index, Sunderland kneads the disparate materials into a kind of scholarly event and source of intellectual pleasure. Both probably presuppose that we ourselves are the witnesses of events that can serve as a lens for us to "recognize" in retrospect in the horrors of the Russian Civil War both the horrendous details as well as the underlying structures. To that extent, the title chosen does not seek to promise too much: Ungern "s "cloak" symbolizes the almost boundless narrative material that an exceptional life under extreme conditions holds in readiness. This material is more than just a decorative accessory. Its basic elements serve the main purpose of the book, namely to write "a history of the Russian Empire in war and revolution." Viewed through the prism of the trajectory of a career that was symptomatic for a whole generation of aristocrats and officers, the upheavals in the Czarist Empire since the turn of the 19th to $20^{\text {th }}$ century take on concrete contours. Biographical details provide access to the great epochal shifts and displacements. They structure a "micro-history" that constantly points to inter-imperial, transnational and supra-personal contexts and connections.

Ungern represents a type of "imperial subject" who discards, step by step, the fetters of social origin and aristocratic life style under the pressure of social and economic changes, yet does not totally deny those shackles. In the turmoil of world war, revolution and civil strife, this new type of aristocrat and adventurer declassé rises to a position of exceptional importance. Resolute, self-confident and unscrupulous, he exploits the opportunity on offer virtually everywhere to acquire power himself, to assemble a band of stalwart followers, to proclaim purported aims and to move on "to action." More or less convincing ideological set pieces, in part of provincial origin, in part imperial in their claims, serve to legitimate an aggressive and transformed elite consciousness.

Ungern's life story begins 1886 in Graz, and leads via Tiflis and Reval to St Petersburg. As if self-evident, he transverses the borders of empires-from Austria-Hungary into Czarist Russia, and later from there on to China. The erratic young man finishes military school with some difficulty and then accepts a first post as officer with the Trans-Baikal Cossacks, safeguarding with them the Russian-Chinese border. In 1913 he quits military service, travels through western Mongolia, and hopes in vain for a post as volunteer in the Mongolian units fighting after the declaration of independence against the Chinese. Shortly after the outbreak of WWI, the aristocratic officer returns to the ranks of the Russian army, serving the Czar in East Prussia, Poland and the Carpathian Mts., as well as on the front in northern Persia. Despite being decorated for special bravery, he repeatedly is the butt of negative attention due to his behavior deemed not "in keeping" with his social rank and status. After Red October, he joins those around the Ataman Grigorii Semenov. Given the rank of Commander, he fights with Semenov's units 
against the Bolsheviks in northern Manchuria along the Chinese Eastern Railway. In the autumn of 1920, as the battles of the Civil War rage on the major fronts, Ungern begins his own very special project - the establishment of a Mongolian Empire to rule between Soviet Russia and China. For a short time, he rises to historical importance and then becomes a man driven by his own utopia.

Sunderland regards every station on Ungern's west-to east journey, heading to the place of his own self-set appointment with destiny, as a juncture of multilayered events. He utilizes that nodal point in order to discuss an epochal problem of the Czarist Empire caught up in crisis. The scenic images of Amur, the Chinese "Black Dragon River," the Siberian border town Kiakhta, of Kobdo in the west and the capital Urga in Mongolia's east, resemble "snap-shots." They spontaneously capture details that disclose more than what is visible and familiar.

How carefully the writer has composed his work is evident from the last section, "The Family Reunion" in the final $11^{\text {th }}$ chapter ("Red Siberia"). Here Ungern's drama reaches its high point. The show trial that his adversaries prepare for and the foreseeable finale before a firing squad form only the frame for a happening now extremely personalized. Sunderland stages the violent act far from the European center as a nodal point of showdown in the entire Civil War, if not even such a conjuncture within the saddle period between 1910 and 1920. The soldier who fired the fatal shot, presumably a Jewish member of the Cheka secret police, and the delinquent warrior, a fanatic anti-Semite, stand face-to-face in an unequal duel. If all the facts are indeed correct, this seems like the artifice of a specialist in dramaturgy, a production artfully staged. A competitor for power, whom the local representatives of the central power recognize solely as a regional prince, is forced to justify himself. But actually, what is decided here vicariously is a struggle for the legacy of the Czarist Empire, its territorial compass, potential and infrastructure. In Sunderland's view, Ungern's case is a revealing illustration of what was at stake in the re-conquest and stabilization of Central Eurasia. What challenged the rule of the Bolsheviks most vehemently was not the credo of the "state nationalists" under the White generals, who aspired to nothing other than the immediate restoration of the "one and indivisible Russia" - but rather the plans of a warlord, which in regard to the prevailing realities were equally as daring as their own. The difference was not about megalomaniac delusions of grandeur, but lay rather in the totally different political goal envisioned. Ungern's obsession, namely to be able to establish a Greater Mongolian Empire, entailed turning away from the center; it meant drawing the borders entirely anew in the East.

Why were the Bolsheviks superior to Baron Ungern? Sunderland's explanation is not that they were even more merciless or cruel, if possible, than Ungern. In Sunderland's view, they drew conclusions from the shared imperial experience different from his. They were more pragmatic when appropriation of old institutions was involved; and they were more innovative in efforts to create loyal institutions of their own - an army, a party, organs of government, an international political network (the Comintern), and revolutionary courts. Meanwhile, Ungern remained a regional fighter, entrapped in the logic of force and counter-force. Here 
Sunderland's argument of a reactionary internationalism probably has its limits. Undoubtedly Ungern "stood for a life that was antidemocratic, reactionary, corrupt, exploitative, deceitful, delusional, murderous, and disloyal" (p. 217). However he sought permanent struggle out at the frontier, without concerning himself with organs of a higher order or a political program bolstered by a vision extending out beyond strictly regional interests. Nor was he concerned about a public language oriented to the state or international allies. The local Cheka that put him on trial was multinational and part of an imperial network, it was not acting autonomously. The Cheka top functionaries were emissaries dispatched from the center and were fulfilling an assignment.

Sunderland has succeeded in presenting an impressive and original history of the Revolution in Eurasia, organized as a "passage through complexities" (p. 11). Encapsulated in the person of Ungern, he shows us a life in imperial contexts, one that has to prove itself and prevail in the maelstrom of chaotic collapse. It is a strange vita activa, one that appears possible only in times of revolution and civil war, the career trajectory of a warrior between movable fronts and shifting adversaries, an echo sounder of irrational slogans and mysticisms. In this confused and convoluted meshwork, Sunderland is superb in his ability to make visible the imperial machinery and its far-flung relay stations, which despite all their heterogeneity possessed centripetal features. Ungern's inner and emotional life is from this perspective secondary. Decisive for an individual's staying power are local governmental practice, the ability to adapt to the dynamics of local societies and the different interlocking cultures. Through close-up shots, we can follow what constitutes an empire, where its strengths lay, and significantly, what it was lacking. Ungern, the aristocrat and officer, stemmed from the periphery and remained rooted in it. He knew the weaknesses of the Empire at its distant margins and sought to exploit them for his own plans.

13 - Leonid A. Iuzefovich, Samoderzhets pustyni: Baron R.F. Ungern-Sternberg i mir $v$ kotorom on zhil [Autocrat fo the desert: Baron R.F. Ungern-Sternberg and the world in which he lived], M., 1993, rev. ed. 2010; Sergei L. Kuz'min, Istoriia Barona Ungerna: Opyt rekonstruktsii [The life of Baron Ungern: A tentative reconstruction], M., 2011; idem, ed., Legendarnyi baron: Neizvestnye stranitsy grazhdanskoi voiny [The legendary baron: Unknown pages of the civil war], M. 2004; idem, ed., Baron Ungern $v$ dokumentakh i memuarakh. [Understanding Baron Ungern through documents and memoirs], M., 2004.

14 - James Palmer, The Bloody White Baron: The Extraordinary Story of a Russian Nobleman Who Became the Last Khan of Mongolia, New York, 2011.

\author{
Nikolaus Katzer \\ German Historical Institute, Moscow
}

